\title{
A PÁRIZSI-FOGYASZTÁSI ÉS -VÁSÁRLÁSI SZOKÁSOK FELMÉRÉSE
}

\author{
Mihalkó József
}

\begin{abstract}
Absztrakt: A húsipar egyik legjellegzetesebb terméke a párizsi vagy parizer, amely nagyon megosztja a fogyasztókat, a gyerekek többnyire szeretik, azonban leginkább a felnőtt emberek igyekeznek elkerülni ezt a húskészítményt az összetétel, valamint a gyártástechnológia mivolta miatt. Kíváncsi voltam arra, hogy napjainkban hogyan alakul ezen termék fogyasztási és vásárlási szokásai. $\mathrm{Az}$ eredmények azt sugallják, hogy a kitöltők kb. 58\%-a fogyaszt párizsit. Többen azért nem fogyasztanak párizsit, mert rossz minőségü, alacsony hústartalmú, egészségtelen terméknek tartják. A válaszadók a párizsi belső tulajdonságait (íz, első benyomás, típus) tartják a legfontosabb szempontnak. Azonban a kérdőív eredményeinek kiértékelése során érzékelhető volt, hogy a fogyasztók zöme nem ismerik a párizsihoz kapcsolódó jogszabályokat, valamint a párizsi gyártástechnológiáját. Példaként említhető az, hogy a párizsi-fogyasztók nagyjából $80 \%$-a nincs tisztában azzal, hogy a parizernek min. 51\% hústartalommal kell bírnia, sokan ennél magasabb hústartalmat várnának el. Emellett bizonyos esetekben érezhető a sok negatív vélemény és a média negatív hatása a termékre nézve (,mert rajta van a WHO rákkeltő listáján”).
\end{abstract}

\begin{abstract}
One of the most typical products of the Hungarian meat industry is the Bologna sausage, which shares consumers very much, children mostly love, but most adults are trying to avoid this meat product because of its composition and manufacturing technology. I was curious about how the consumption and purchase habits of this product are changing nowadays. The results suggest that approximately $58 \%$ of the respondents consume Bologna sausage. Many people do not eat this because they consider its poor quality, small meat content, unhealthy product. The respondents consider the properties of Bologna sausage (taste, first impression, type) to be the most important aspect. However, during the evaluation of the survey results, it was felt that most consumers are unfamiliar legislation relating to Bologna sausage and manufacturing technology of Bologna sausage. As an example, around $80 \%$ of consumers of Bologna sausage do not know that it should have a meat content of min. $51 \%$, many would expect a higher meat content than this. In some cases, it can feel a lot of negative opinions and the negative impact of the media on the product ("because it's on the carcinogen list of WHO").
\end{abstract}

Kulcsszavak: párizsi, húskészítmények, kérdőíves felmérés, fogyasztási szokások, vásárlási szokások Keywords: bologna sausage, meat products, survey, consumption habits, purchase habits

\section{Bevezetés}

A húskészítmények közé azon húsipari termékek tartoznak, amelyeket humán táplálkozás céljára állítanak elő, ezek húsipari nyersanyagokból (pl. szalonna, hús), íz- és jellegkialakító anyagok segítségével készítenek meghatározott technológia mentén (Mihalkó-Zsarnóczay, 2019). A húskészítmények közé nagyon sok terméket tudunk felsorolni, például ide tartozik a párizsi, virsli, szalámik, kolbászok, sonkák, felvágottak. A hatályos magyarországi húskészítményekkel kapcsolatos szabályozás (A Magyar Élelmiszerkönyv 1-3/13-1 számú elöírása) található meg, amelyben pontosan megjelennek az alapfogalmak (pl. hús, csontokról mechanikailag lefejtett hús, füstölés, érlelés, fözés). 4 termékcsoport - felvágottak, sonkák, érlelt kolbászok, szalámik - definíciója, minőségi, kémiai és érzékszervi jellemzői, előírt neve, valamint a 14 darab termék - többek között párizsi vagy parizer, virsli, nyári turista 
felvágott, Zala felvágott, téliszalámi - definíciója, minőségi, kémiai és érzékszervi paraméterei, elöírt neve van meghatározva.

Szakály (2017) szerint a különböző húsféleségek vásárlásakor fontos szempontnak számít a termék kinézete, állománya, valamint az ára. Emiatt szeretném bemutatni 4 különböző húskészítmény - szárazkolbász, gépsonka, párizsi, illetve olasz felvágott - kilogrammonkénti fogyasztói átlagárát, amelyet az 1. ábrán tüntettem fel a (Központi Statisztikai Hivatal, 2021a) adataira hivatkozva, ahol látható az, hogy az elmúlt 6 évre nézve nagyrészt minden évben emelkedett az egyes hústermékek kilogrammonkénti fogyasztói átlagára, kivétel figyelhető meg a 2015., 2016. és 2017. években bizonyos termékek esetén, pl. a gépsonka ára csökkent mindhárom évben az előző évhez képest. Az elmúlt 3 évben kivétel nélkül emelkedett az alábbi termékek fogyasztói átlagára, a legnagyobb mértékben a 20192020. években, a párizsi és olasz felvágott esetében látható majdnem $20 \%$-os növekedés (19,86\% és 19,62\%). A szárazkolbász fogyasztói átlagára 2014 januárja óta $25,16 \%$-kal, a gépsonka fogyasztói átlagára 17,67\%-kal, a párizsi és az olasz felvágott ára majdnem 40\%-kal emelkedett (36,72\% és 37,96\%).

\section{1. ábra: Húskészítmények kilogrammonkénti fogyasztói átlagára}

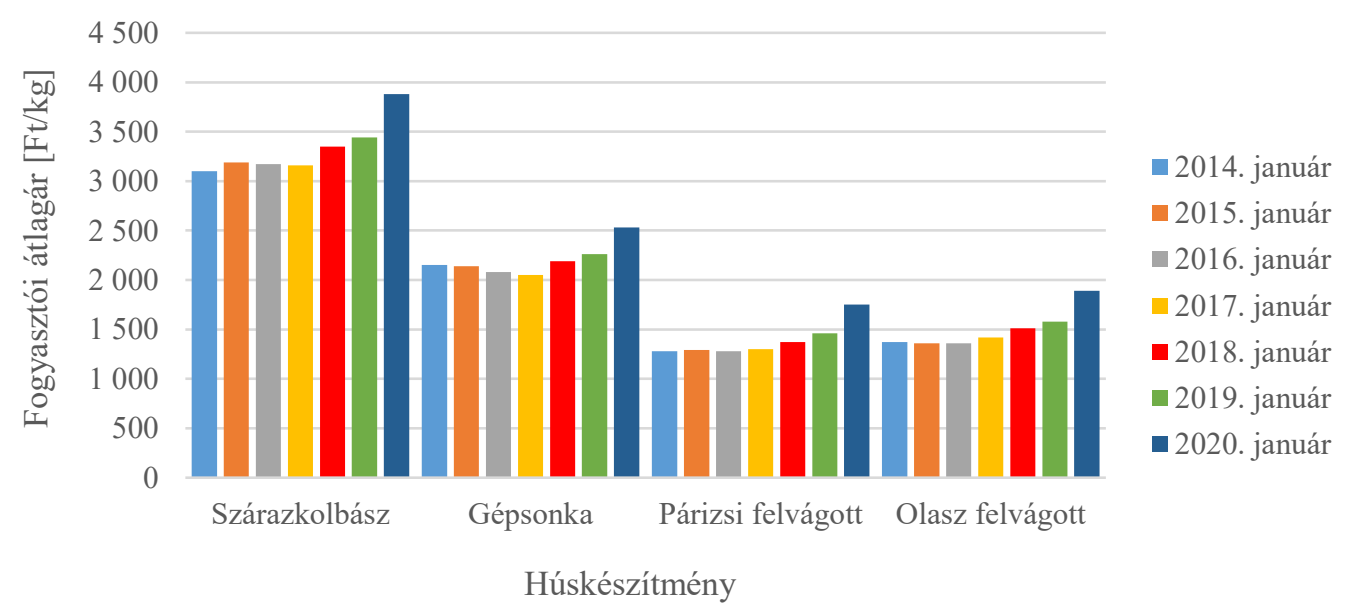

Forrás: Központi Statisztikai Hivatal (2021a)

A párizsi vagy parizer olyan húskészítmény, amelynek minimális átmérője 55 $\mathrm{mm}$, a húspépét természetes vagy mübélbe töltik, a homogén metszéslapú terméket főzéssel hőkezelik. A parizer lehet füstöletlen, füstölt vagy füst ízesítésủ. Fontos még az, hogy a jelölés szempontjából a hústartalomnak a késztermékre vonatkoztatva legalább 51\%-ot el kell érnie. A csontokról mechanikusan lefejtett hús mennyisége ezen felül a késztermékre vonatkoztatva legfeljebb 10\% lehet (A Magyar Élelmiszerkönyv 1-3/13-1 számú előírása).

Ha alaposabban megnézzük a párizsi éves átlagos fogyasztói árát, akkor - mint az a 2. ábrán is jól látható - 1996. év óta évröl-évre folyamatosan nőtt (1999-ben és 2003-ban csökkent) (Központi Statisztikai Hivatal, 2021b). 


\section{2. ábra: Párizsi kilogrammonkénti fogyasztói átlagára - évi lebontás}

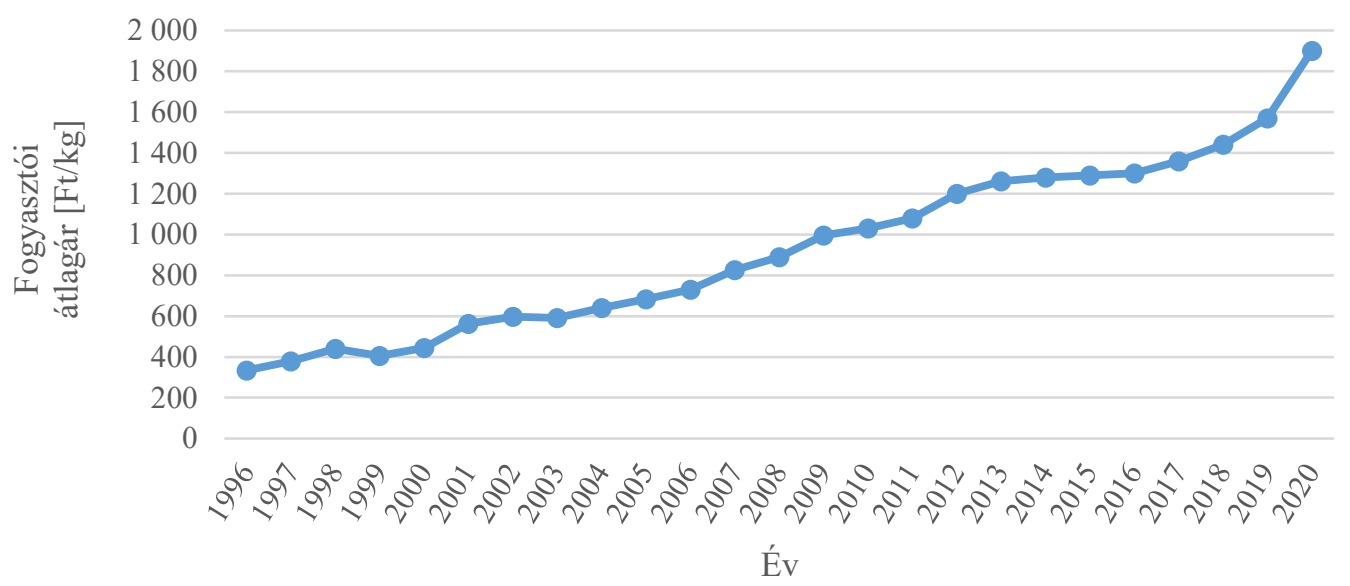

Forrás: Központi Statisztikai Hivatal (2021b)

Itt is megfigyelhető, hogy a legnagyobb mértékü emelkedések 2000. és 2001. évi (26,29\%), valamint 2019. és 2020. évi éves átlagos fogyasztói ár között volt (21,02\%), legtöbb esetben csak 5-10\% emelkedés volt évenként. Összességében pedig megállapítható, hogy az 1996. év óta a 100\%-os árnövekedést 2005-ben értük el, 200\%-os emelkedés 2010-ben, 300\%-ost 2017-ben, 2020-ban pedig már 468,86\%-os árnövekedésnél járunk.

Szakály (2017) szerint a világ egy före jutó húsfogyasztása 41,3 kg volt, ennek körül-belül 60\%-át sertés és baromfi húsának fogyasztásából tevődik össze, 2019. évben a hazai húsféleségek egy före jutó fogyasztása $68,8 \mathrm{~kg} /$ fö/év volt, amelynek körül-belül 63\%-a tőkehús fogyasztására fordítódott (Központi Statisztikai Hivatal, 2021c). Az elmúlt évek egy före jutó tőkehúsainak hazai fogyasztási mennyiségeiből azt vehetjük észre (3. ábra), hogy a leggyakrabban fogyasztott tőkehúsnak a baromfihús (2019: 23,1 kg/fö/év) és a sertéshús (2019: 19,2 kg/fö/év) számít, amelyeket nagyon kis arányban követ a marha- és borjúhús (2019: $1 \mathrm{~kg} / \mathrm{fö} / \mathrm{e} v$ ), valamint a juh-, kecske-, nyúl- és egyéb hús (2019: 0,1 kg/fö/év) fogyasztása. A baromfi- és sertéshús fogyasztás esetében az figyelhető meg még, hogy az évek elörehaladtával növekedés figyelhető meg (2010 és 2019 között a baromfihúsnál 6,6 $\mathrm{kg} /$ fö/év, sertéshúsnál $3,5 \mathrm{~kg} /$ fö/év értékü növekedés látható), a többi hús esetén stagnálás vehető észre (Központi Statisztikai Hivatal, 2021c).

A 3. ábrán látható néhány húskészítmény - szalámi, szárazkolbász és sonka; egyéb hentesáru; belsőség; valamint mirelit hústermékek, húskonzervek - egy főre jutó hazai fogyasztása. A 2019. évben némileg nagyobb mennyiségben fogyasztottak szalámit, szárazkolbászt és sonkát (összesen $11 \mathrm{~kg}$ /fö/év) - ezt Szakály (2017) is megerősíti -, mint egyéb hentesárut (pl. párizsit, virslit) 9,5 kg/fö/év értékben. Ehhez képest közel negyed mennyiséget ért el a 2019. évi mirelit hústermékek, húskonzervek (2,7 kg/fö/év), illetve belsőség ( $2,2 \mathrm{~kg} /$ fö/év) hazai fogyasztása. Az elmúlt évek tendenciáit megfigyelve észrevehető az, hogy a szalámi, szárazkolbász és sonka fogyasztása közel kétszeresére emelkedett 2010 és 2019 között, az egyéb 
hentesáruk elmúlt évtizedbéli fogyasztására a folyamatos változás, a belsőség fogyasztására folyamatos csökkenés, a mirelit hústermékek és húskonzervek fogyasztására növekedés jellemző (Központi Statisztikai Hivatal, 2021c).

\section{3. ábra: Húsfélék egy fốre jutó magyarországi fogyasztása (kg/fô/év) - évi lebontás}

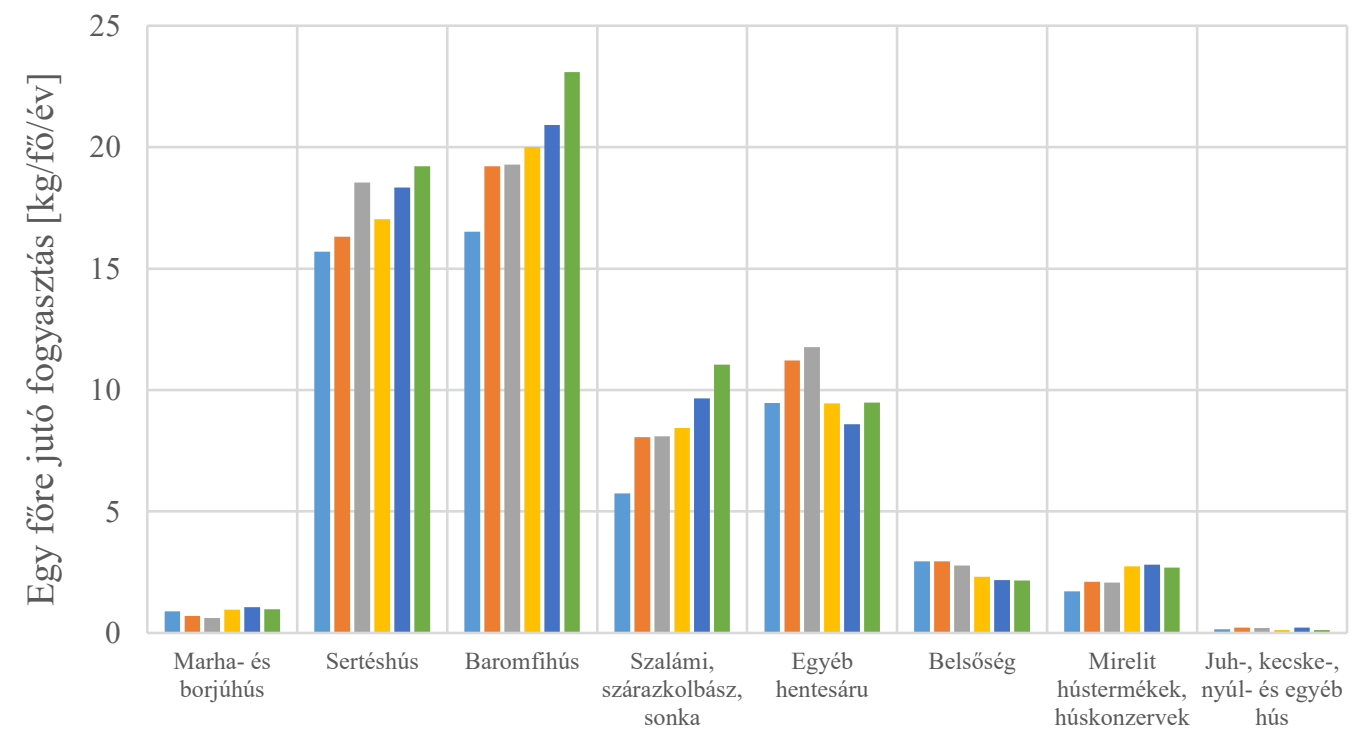

Húsfélék

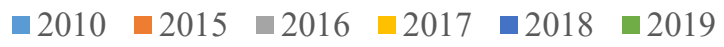

Forrás: Központi Statisztikai Hivatal (2021c)

Kesjár et al. (2017) vizsgálta a hazai kolbászfogyasztási és -vásárlási szokásokat, amelyből kitünik az, hogy a megkérdezettek közel 90\%-a fogyaszt kolbászt, többségük a csípős és a csemege kolbászokat kedveli. A kolbászvásárlás során legfontosabb tényezőként a korábbi elégedettséget és a termék kinézetét, színét nevezte meg, ezt követően fontos szempontnak az összetétel, illetve az ismerősök véleménye számított, a termék ára csak az 5 . legfontosabb tényező volt.

\section{Vizsgálati módszer}

A kérdőíves felmérés készítése során a párizsi vásárlási és fogyasztási szokásokat mértem fel. Azt szerettem volna kideríteni, hogy többek között a húskészítményeken belül mennyire kedvelt termék a párizsi, milyen állatfaj húsából készült párizsikat kedvelik a fogyasztók. Felmértem azt is, hogy a fogyasztók mennyire vannak tisztában a párizsi hústartalmához kapcsolódó jogszabállyal.

A kérdőíves felmérés 2018 öszén tartott, mely időszakban 323 válasz gyült össze (Mihalkó, 2021). 


\section{Eredmények és értékelésük}

A honlapon (Mihalkó, 2021) található kérdőív eredményeinek összesítéséhez és kiértékeléséhez a Microsoft Office 365 Excel programot használtam.

A felmérést elsőként a megkérdezettek húskészítmények és párizsik fogyasztási szokásainak vizsgálatával kezdtem. Ezután következtek a párizsi-vásárlási szokásokra vonatkozó kérdések, végezetül a demográfiai kérdések zárták az ürlapot. Az összes válaszadó 323 fö volt.

Az 1. táblázat tartalmazza a kitöltők demográfiai adatait.

\section{1. táblázat: A válaszadók demográfiai adatait összefoglaló táblázata $(n=323)$}

\begin{tabular}{|c|c|c|c|}
\hline Jellemzők & Szocio-demográfiai változók & $\begin{array}{c}\text { Válaszadók } \\
\text { száma }\end{array}$ & $\begin{array}{c}\text { Megoszlás } \\
{[\%]}\end{array}$ \\
\hline \multirow[t]{2}{*}{ Nem } & Nő & 213 & 65,9 \\
\hline & Férfi & 110 & 34,1 \\
\hline \multirow[t]{5}{*}{ Életkor } & 18 év alatt & 1 & 0,3 \\
\hline & $18-25$ év & 202 & 62,5 \\
\hline & $26-45$ év & 93 & 28,8 \\
\hline & $46-65$ év & 25 & 7,7 \\
\hline & 65 év fölött & 2 & 0,6 \\
\hline \multirow[t]{7}{*}{ Foglalkozás } & Diák/Hallgató & 154 & 47,7 \\
\hline & Alkalmazott & 135 & 41,8 \\
\hline & Vállalkozó & 15 & 4,6 \\
\hline & Vezető & 10 & 3,1 \\
\hline & Munkanélküli & 5 & 1,5 \\
\hline & Nyugdíjas & 3 & 0,9 \\
\hline & Háztartásbeli & 1 & 0,3 \\
\hline \multirow[t]{4}{*}{ Lakóhely } & Megyeszékhely & 129 & 39,9 \\
\hline & Város & 113 & 35,0 \\
\hline & Község/ Falu & 47 & 14,6 \\
\hline & Főváros & 34 & 10,5 \\
\hline \multirow{5}{*}{$\begin{array}{l}\text { Anyagi } \\
\text { helyzet }\end{array}$} & Jelentősen átlag feletti & 2 & 0,6 \\
\hline & Átlag feletti & 63 & 19,5 \\
\hline & Átlagos & 231 & 71,5 \\
\hline & Átlag alatti & 25 & 7,7 \\
\hline & Jelentösen átlag alatti & 2 & 0,6 \\
\hline
\end{tabular}

Forrás: A szerző saját szerkesztése

A kérdőívre valamivel kevesebb, mint kétszerannyi nő válaszolt, mint férfi. A legtöbb személy 18 és 45 év közötti korosztályból került ki, többségük oktatási intézménybe jár tanulóként, vagy alkalmazottként dolgozik és átlagos jövedelmi szinttel rendelkezik. A válaszadók döntően megyeszékhelyen vagy városban élnek. 


\subsection{Párizsi-fogyasztási szokások}

A kérdőív első részében többek között arra voltam kíváncsi, hogy a válaszadók fogyasztanak-e húskészítményeket, milyen termékeket fogyasztanak és kedvelnek, ezen belül is elsődlegesen a párizsikra fordítva a figyelmet. A kitöltők 95\%-a (307 fö) fogyaszt húskészítményeket, a maradék 5\% (16 fö) közül 6 személy vegán vagy vegetáriánus életmódot folytat, hárman undorodnak a húskészítményektől, a többiek közül kiemelnék pár indokot. Az első esetén az egyik kitöltő a szakmájára kereskedö - hivatkozik, s ennek következtében „tudja, hogy mit tartalmaznak ezek a termékek...”. A másik két indoknál viszont azért nem fogyasztanak húskészítményeket, „mert rajta van a WHO rákkeltő listáján”, valamint „egészségtelenek, károsak az emberi szervezetre”. Itt a média negatív hatását említeném meg a legfontosabb okként (HVG, 2021), ennek a 2015-ben történt médiahírverésnek köszönhetően is csökkent a húskészítmény-fogyasztók száma.

Következő lépésben a húskészítményt fogyasztóktól megkérdeztem a kedvelt termékeket (többet is be lehetett jelölni), amely összefoglalása látható a 4. ábrán. Itt az olvasható le, hogy a 307 fó majd 90\%-a szívesen fogyasztja a sonkaféléket, virsliket, a párizsi esetében valamivel több, mint a megkérdezettek fele ez az érték.

\section{4. ábra: A húskészítmények \%-ban kifejezett fogyasztói kedveltsége (n=307)}

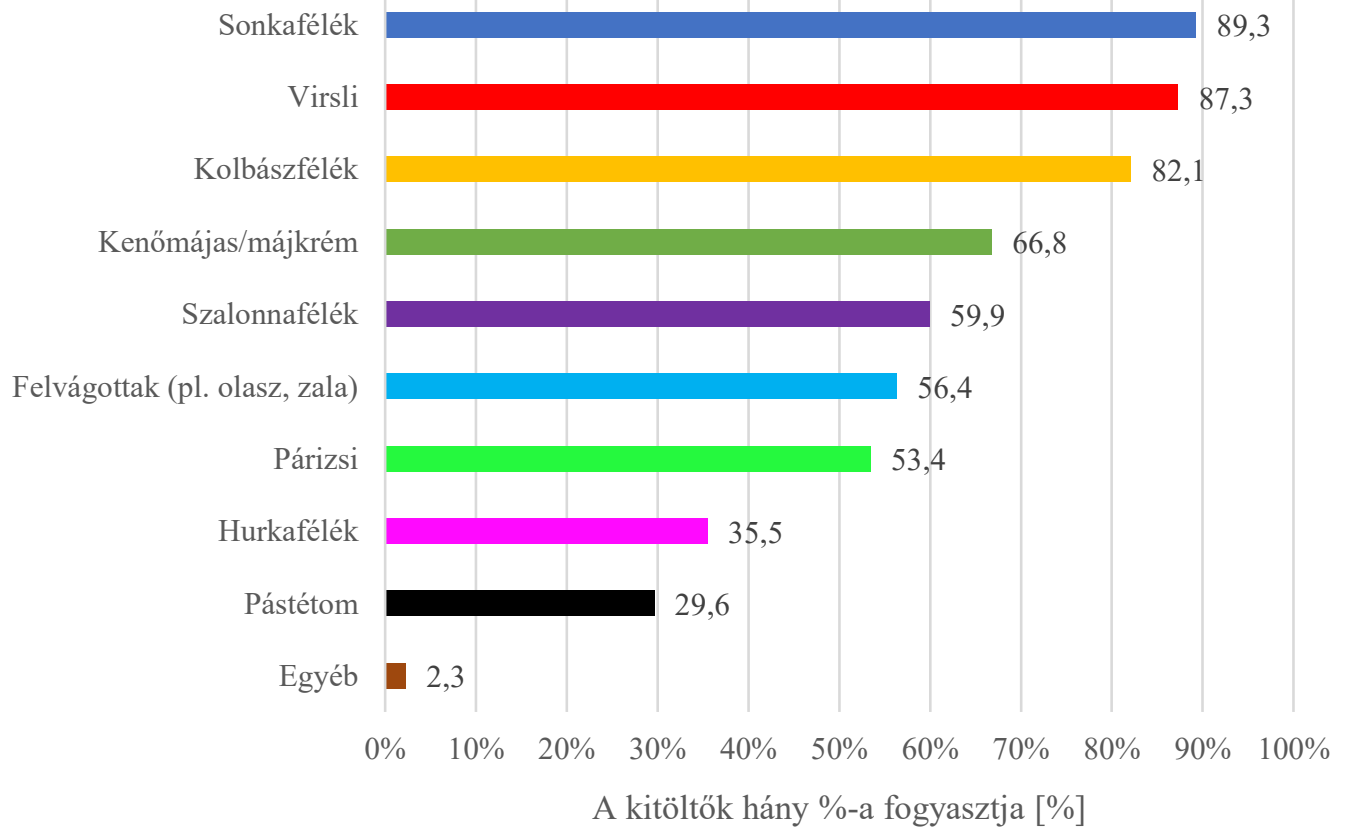

Forrás: A szerző saját szerkesztése

Ezután arra voltam kíváncsi, hogy ténylegesen melyik a kitöltők kedvenc terméke, ahol az első helyezett a sonkafélék lettek - a felmérésben résztvevők 43,6\%-ának a legszeretettebb húskészítménye, a kolbászféléket megelőzve. A 
párizsi ebben a listában is a második felében található meg, a kitöltők 4,9\% szereti a leginkább (5. ábra).

\section{5. ábra: A legkedveltebb húskészítmények (\%-ban kifejezett értékek) (n=307)}

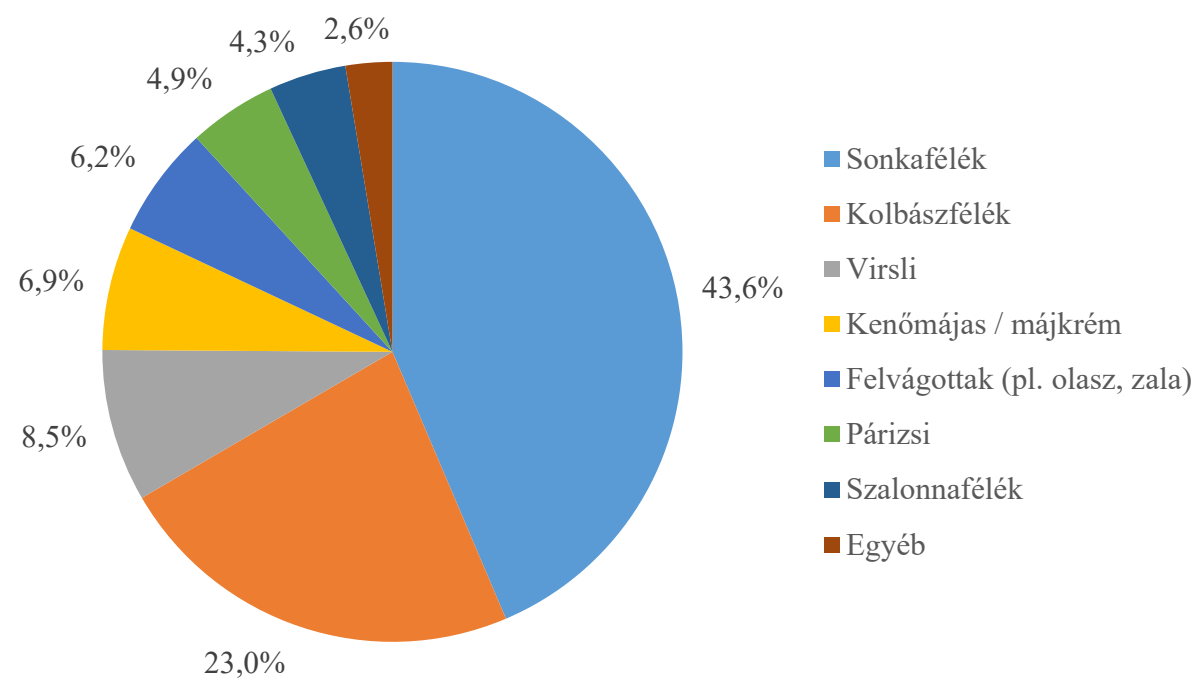

Forrás: A szerző saját szerkesztése

Emellett még feltettem egy kérdést a húskészítmények fogyasztásának gyakoriságával kapcsolatban, ahol azt az eredményt kaptam, hogy a felmérésben résztvevők kb. 65\%-a naponta legalább egyszer eszik húskészítményt, heti egy alkalommal ritkábban csak 3,6\%-a él ilyen termékekkel.

A továbbiakban a húskészítményt fogyasztók (307 fö) esetében kíváncsi voltam a párizsi-fogyasztási szokásokra. A megkérdezettek 60,6\%-a (186 fö) fogyaszt párizsit, azonban 39,4\% (121 fö) különbözö okok miatt nem. 121 fö (kb. 40\%) nem szereti ezt a terméket, undorodik tőle. Sokan a minőségre, az alacsony hústartalomra - egy kitöltő a válasza alapján olyan húskészítményeket fogyaszt, amelynek a minimális hústartalma $98 \%$-, az összetevőkre (pl. adalékanyagokra, magas sótartalomra, ,ismeretlen összetevőkre” gondolnak) panaszkodnak. Nem tartják egészségesnek, illetve „tudják”, hogy milyen anyagokból készítik a parizereket, s emiatt kerülik a fogyasztását, ezen fogyasztók nem biztos, hogy tisztában vannak az egészséges táplálkozás fontosságával (Szabó, 2018).

Pár kitöltő ellenérzését fejtette ki az adalékanyagokkal kapcsolatban. Az egyik kitöltő szerint: „Nem győzött meg az összetevő lista, hogy nem fogok tőle meghalni.” Olvasható olyan indoklás is, hogy „nincs benne annyi tápanyag, hogy megérje megvenni. Az E-számok meg az ízfokozók meg nem finomak. Kutyának sem venném meg." Az érezhető a válaszokból, hogy bizonyos kitöltők nincsenek tisztában az élelmiszer-adalékanyagokra vonatkozó jogszabályokkal. Hiszen az Európai Unió szerint adalékanyagok közé tartoznak az olyan anyagok, amelyeket önmagukban élelmiszerként nem fogyasztják, valamint nem alkalmazzák 
élelmiszerek jellemző összetevőjeként. Emellett csak akkor szerepelhetnek az engedélyezett adalékanyagok listáján (vagyis rendelkezik E-számmal), amennyiben humán egészségi szempontból biztonságosnak tekintette az Európai Élelmiszerbiztonsági Hatóság (EFSA), a biztonságosságot megadott időnként újra kell értékelnie az EFSA-nak (1333/2008/EK rendelet az élelmiszeradalékanyagokról; Európai Bizottság, 2021; Nébih, 2021).

Néhányan gyermekkorukban szívesen fogyasztották, azonban felnőttkorukra megunták. További érdekesebb válaszok között szerepel többek között az, hogy az adott kitöltő szárnyast eszik, de a párizsik sertéshúst gyakran tartalmaznak, emiatt nem fogyasztja. Ez nem feltétlen igaz kijelentés, pl. az eFeF baromfi párizsi nem tartalmaz egyáltalán sertéshúst. Egyik kitöltő szerint a parizert „,szinte csak vízből és másra fel nem használható állati eredetủ maradványból” gyártják. A válaszok között találkozhatunk olyan indoklásokkal, hogy az alacsony ára miatt nem fogyasztja a párizsit; valamint „a természetes húskészítményeket részesítem előnyben”, a parizer „mü, az összes közül a legmübb”, „,hamar megromlik”, „találtam már benne szőrt és csontot”. Emellett páran a parizert „húsipari mellékterméknek”, „darált ipari szemétnek”, „sok mindenből összedarált mosléknak”, „a húsfeldolgozás hulladékaiból készült terméknek” tartják. Emellett volt olyan vélemény is: „Nem merek belegondolni, hogy mi lehet benne. (Bár a virslit is elhagyhatnám. Az is hasonló kategória.)" Mindezek alapján megállapítható az, hogy a fogyasztók egy része nem eléggé tájékozott a párizsi összetételével, hústartalmával, sőt egyáltalán a húskészítményekkel kapcsolatban sem.

Ez utóbbihoz kapcsolódóan megkérdeztem a párizsi-fogyasztókat arról, hogy szerintük minimálisan hány \% húst szükséges tartalmaznia a párizsinak, amely érték min. 51\% (a Magyar Élelmiszerkönyv 1-3/13-1 számú elöírása). A kérdésre válaszoló 161 főből összesen 21,7\% (35fö) tudta helyesen ezt az értéket, a maradék $78,3 \%$ (126 fö) minél szélesebb palettán tippelt helytelenül a minimális hústartalom értékére. Elöfordult a tippek között a 0,5,10,12, 15, 80, 87, 90, 99, amelyek közül pl. a $60 \%$-ra, a $70 \%$-ra és a $80 \%$-ra is a kitöltők $12,4 \%-12,4 \%$-a nem tudta helyesen a választ. Ez továbbra is megerősíti azt, hogy az emberek egy része nem igazán van tisztában a párizsival kapcsolatos szabályozásokkal.

A folytatásban a következő kérdések segítségével azt kívántam megnézni, hogy a párizsi-fogyasztók márkához tudják-e kötni ezt a terméket. Elsősorban 2 darab márka - összesen $18 \mathrm{db}$ - jutott a kitöltők eszébe, a Pick és a Sága, amelyek között a Pick márka többször fordult elö. A megkérdezettek közel 60\%-a a Pickhez, valamint nagyjából 15\%-a a Ságához köti márka szempontjából ezen húskészítményt. Ezzel összeköthető, hogy a fogyasztók közel 62\%-ának kedvenc márkája a Pick, 17\%-ának a Sága, azonban ki kell emelni, hogy 2 kitöltő helytelenül említette meg a kedvenc párizsi márkájaként a Sága Falni Jó! Csemege termékét, hiszen ezt nem nevezhetjük párizsinak a 41\%-os MSM-tartalma (csontokról mechanikusan lefejtett hús) és a $0 \%$-os hústartalma miatt. A résztvevőktől még azután megérdeklődtem, hogy más márka is beugrik-e a párizsi szó hallatán. Ekkor elsődlegesen a fogyasztók 20\%-a a Ságát, 15\%-a a Picket és a Kométát említette, a 
többi 27 márka mellett, emellett 4 db Zala felvágottat, valamint 3 esetben a Sága Falni Jó! Csemege terméket párizsi márkaként jelölték meg helytelenül.

Ezt követően a párizsi-fogyasztóktól az iránt érdeklődtem, hogy milyen állat húsából készült párizsit kedvelnek (itt is többet be lehetett jelölni). Az első helyezett a kitöltők 63,8\%-a által kedvelt sertéspárizsi volt, amelyet a baromfipárizsi $(48,1 \%)$, a pulykapárizsi (40\%), valamint a marhapárizsi (36,2\%) követett (6. ábra).

\section{6. ábra: Mely állatfaj húsából készült párizsit kedvelik a fogyasztók (\%-ban kifejezett értékek) $(\mathrm{n}=185)$}

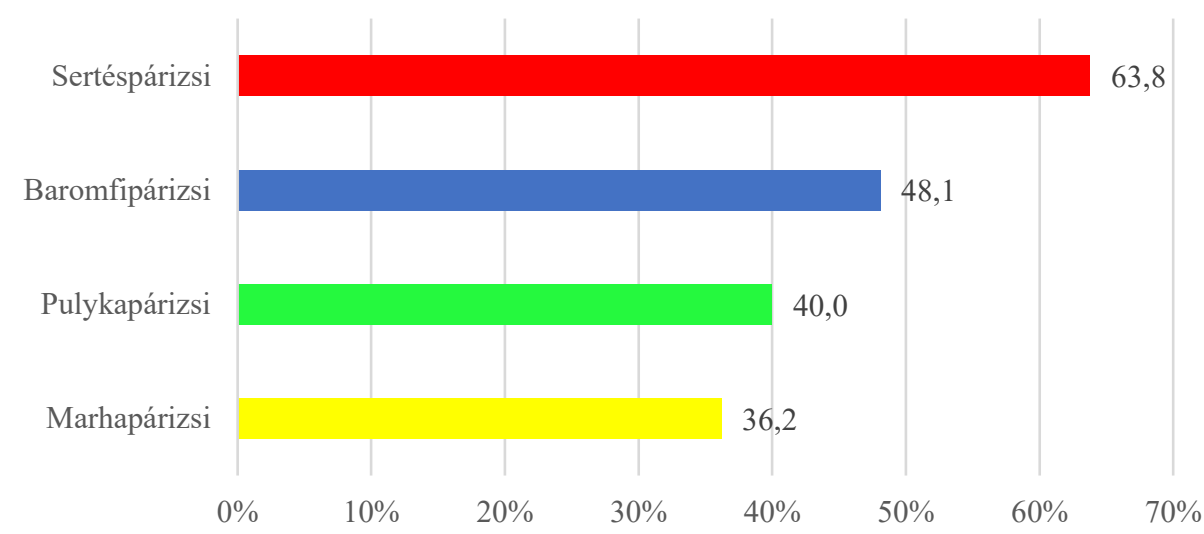

Forrás: A szerző saját szerkesztése

\subsection{Párizsi-vásárlási szokások}

Az utolsó nagyobb témakörben a párizsi-vásárlási szokásokat vizsgáltam a kitöltők segítségével. Először az érdekelt, hogy a 323 főből hány vásárol párizsit. Az adatokból azt állapítottam meg, hogy a felmérésben résztvevők 53,6\%-a (173 fó) veszi ezt a húskészítményt, ellentétben a maradék 46,4\%-ával (150fö). A következö kérdésem ezen termék vásárlásának gyakoriságát firtatta, amelyre nagy megoszlás a jellemző. Leggyakrabban havonta vásárolnak párizsit a vevők 28,5\%-a (49fö), ezt követi 23,3\%-kal a kétheti, 19,8\%-kal a hetente egy alkalommal, 15,1\%-kal a havi alkalom-hoz képest ritkábban, $11 \%$-kal a hetente több alkalommal, végezetül pedig 2,3\%-kal a naponta vásárlók köre.

Emellett rákérdeztem az egy vásárlásnál megvásárolt mennyiségre is, ahol az figyelhető meg, hogy a vevők 58,1\%-a 15-30 dkg-ot, 24,4\%-a kevesebbet, 17,5\%-a többet vesz egy alkalommal. A kiszerelés tekintetében pedig az a jellemzö, hogy kb. 78\%-ban szeletelt formában vásárol párizsit, nem pedig rúdban.

Kíváncsi voltam arra is, hogy milyen összeget fizetnek parizerért a vásárlók, valamint hol történik jellemzően a termékek beszerzése. A megkérdezettek túlnyomó többsége egy-egy bevásárlás során legfeljebb 750 forint értékben vesz párizsit, továbbá ezen belül a vásárlók 60\%-a igyekszik 251-500 forintot költeni ezen húskészítményre (7. ábra). 
7. ábra: A válaszadók mennyit költenek egy bevásárlás során párizsira (\%-ban kifejezett értékek) $(n=171)$

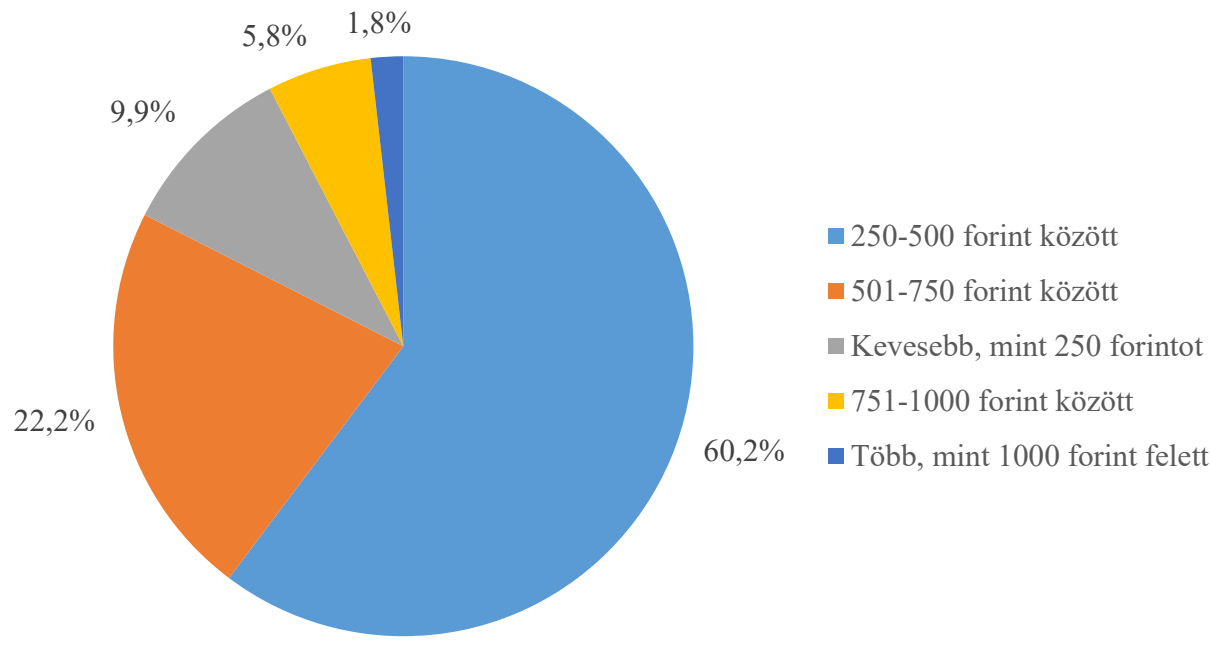

Forrás: A szerző saját szerkesztése

A kitöltők zöme (81\%) hiper-vagy szupermarketben vásárol parizert, körül-belül 40-40\%-uk vásárol kisközértben, valamint diszkontban (pl. Penny Market), a nagyobb választéknak és húspultnak köszönhetöen (8. ábra).

\section{8. ábra: A párizsik beszerzési helye (\%-ban kifejezett értékek) (n=171)}

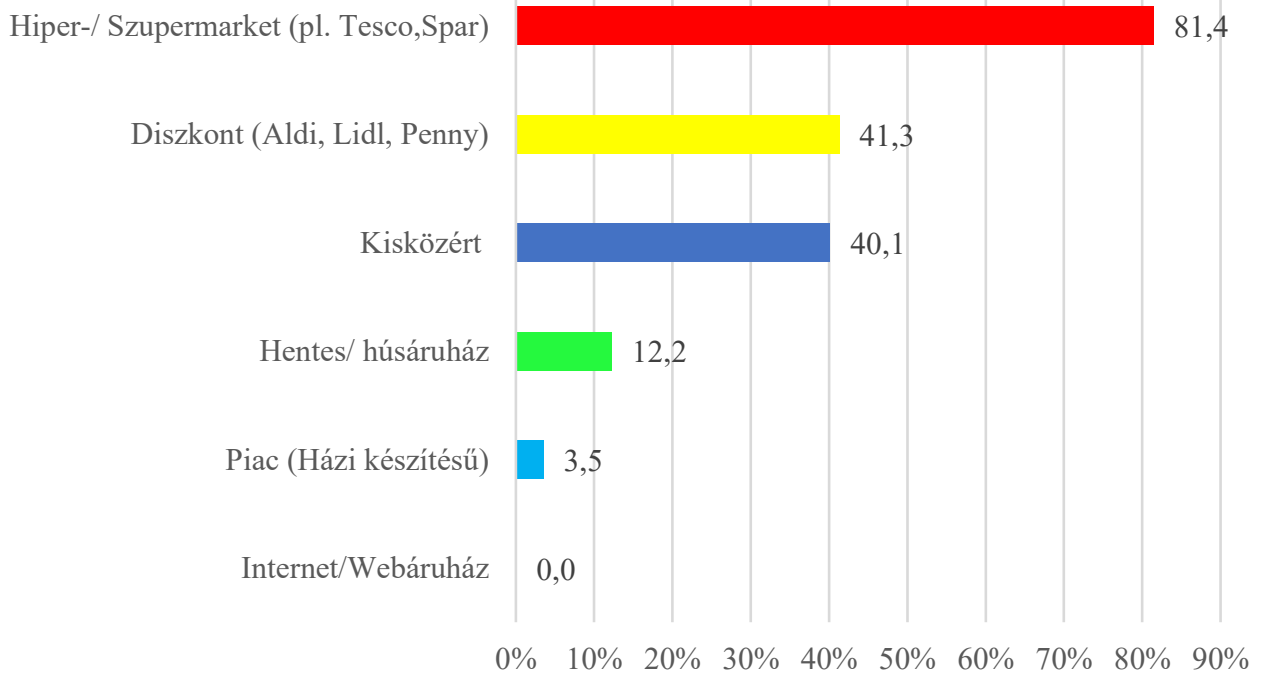

Forrás: A szerző saját szerkesztése 
A márkahüségre vonatkozó kérdéseimmel annyit sikerült megállapítanom, hogy a vásárlók kb. 60\%-a legtöbbször ugyanazt a márkát vásárolja, további durván 20\%a viszont ugyanazt veszi. Amennyiben pedig nem így történik, vagyis más márka kerül bele a kosárba, akkor többek között a vevők kb. 50-50\%-a nem találja meg a kedvenc párizsit, vagy egy másik terméket akciós áron kapja. Valamivel több, mint 25\%-uk szeretik a változatosságot, nagyjából 20\%-uk pedig kipróbálják az újdonságokat.

A kérdőívben arra kértem a kitöltőket, hogy számukra fontosságuk szempontjából osztályozzanak vásárlással kapcsolatos szempontokat. 1-től 5-ig kellett pontozniuk ( 1 - kevésbé fontos, 5 - nagyon fontos). A válaszadók válaszait (pontszámait) átlagoltam, valamint az egyes szempontokat ezen átlagok (átlagértékek) alapján sorba rendeztem, így láthatóvá vált az, hogy jellemzően mely tényezőket ítélik legfontosabbnak vásárláskor (2. táblázat).

\section{2. táblázat: Párizsi-vásárlási szempontok prioritási sorrendjének statisztikai} adatai $(n=170)$

\begin{tabular}{|l|l|c|c|c|c|}
\hline Sorszám & Szempont & Átlagérték & Szórás & Módusz & Medián \\
\hline 1. & Mennyire ízlik? & 4,68 & 0,75 & 5 & 5 \\
\hline 2. & Első benyomás & 4,49 & 0,82 & 5 & 5 \\
\hline 3. & $\begin{array}{l}\text { A párizsi típusa (pl. } \\
\text { füstös, sajtos) }\end{array}$ & 4,00 & 1,10 & 5 & 4 \\
\hline 4. & Márka/ Gyártó & 3,86 & 1,07 & 5 & 4 \\
\hline 5. & Húsfajta & 3,85 & 1,09 & 4 & 4 \\
\hline 6. & Minőség & 3,60 & 1,17 & 3 & 4 \\
\hline 7. & Ár & 3,54 & 1,23 & 5 & 4 \\
\hline 8. & Csomagolás & 2,47 & 1,15 & 3 & 2 \\
\hline 9. & Mások véleménye & 2,19 & 1,12 & 1 & 2 \\
\hline 10. & Reklámok & 2,06 & 1,30 & 1 & 2 \\
\hline 11. & $\begin{array}{l}\text { Egyéb (pl. laktóz- } \\
\text { mentes stb.) }\end{array}$ & 1,72 & 0,84 & 1 & 1 \\
\hline
\end{tabular}

Megjegyzés: Az átlagértékek értelmezése 1-től 5-ig terjedő végpontskálán történik, ahol $1=$ kevésbé fontos, 5 = nagyon fontos. Forrás: A szerző saját szerkesztése

A válaszok alapján megállapítható, hogy a válaszadók a párizsi belső tulajdonságait tartják a legfontosabb szempontnak. Annak íze, első benyomása, típusa (pl. füstölt, sajtos) befolyásolja őket leginkább a vásárlás során. Csupán a 7. legfontosabb szempontként következik a termék ára, amelyet nem sokkal előz meg a minőség, a húsfajta és a márka. A csomagolás jellege, mások véleménye és a reklámok kevésbé befolyásolják a kitöltőket a parizervásárlás tekintetében. Jóllehet sok esetben azt gondolnánk, hogy az ár alapján dönt a fogyasztó, a legnagyobb pontátlagot mégis az íz kapta. 


\section{Következtetések, összegzés, záró megjegyzések, záró gondolatok}

Az egyik legsajátosabb magyar húskészítménynek számít a párizsi vagy parizer, amely sokféle hatást vált ki a fogyasztókból, a gyerekek többségében szeretik, azonban föként a felnőttek kerülik ezeket (pl. az összetételük miatt).

A jelen cikk alkalmával arra kerestem a választ, hogy milyen a párizsi fogyasztói kedveltsége, milyen indokok miatt nem fogyasztják ezeket a termékeket, valamint hogyan alakulnak a vásárlási szokások.

A 323 megkérdezett 95\%-a fogyaszt bármilyen húskészítményt, a többiek jelentős része vegetáriánus vagy vegán életmódot folytat, emellett néhányan undorodnak vagy egészségteleneknek tartják ezeket a termékeket (média negatív hatása is érződik pár válaszból: „mert rajta van a WHO rákkeltő listáján”.). A húskészítmény-fogyasztók közel $65 \%$-a eszik naponta minimum egyszer húskészítményt. A húskészítmény fogyasztók zöme kedveli a sonkaféléket, virsliket, 53,4\%-a fogyasztja szeretettel a párizsit. Kedvenc terméknek a sonkafélék számítanak (közel 44\%-os aránnyal), ennek az értéknek majdnem a tizedének (4,9\%) a kedvence a párizsi.

A húskészítmény-fogyasztók csaknem $61 \%$-a parizer-fogyasztónak számít, a többi kitöltő közül sokan az összetételt, alacsony minőséget és hústartalmat jelölték meg indokként. Több érdekes indok is elhangzott, amelyekböl az látható, hogy pár kitöltő nincs tisztában az adalékanyagokkal vagy a húskészítményekkel kapcsolatos hatályos jogszabályokkal vagy a párizsik gyártástechnológiájával kapcsolatban. Ez kiderült akkor is, amikor a kitöltőket megkérdeztem a párizsik minimális hústartalom határértékéről (51\%), a párizsi-fogyasztók nagyjából 22\%-a ismerte az alábbi értéket, többiek válaszai között előfordult a $0 \%, 5 \%, 10 \%, 12 \%, 15 \%, 80 \%, 87 \%$, 90\%, 99\%-os érték is. Azonban Mihalkó és Zsarnóczay (2019) alapján nem biztos, hogy sokkal jobb lesz egy adott termék érzékszervi szempontból, ha az magasabb hústartalommal rendelkezik. Ugyanis a legmagasabb - 90\% fölötti -hústartalmú párizsi az érzékszervi bírálat során csak a 10. legkedveltebb terméknek számított 11 termék közül.

A parizer-vásárlás 5. legfontosabb szempontja az volt, hogy milyen állatfaj húsából készül a termék. A párizsi-fogyasztók körében a legkedveltebbnek (közel 64\%) számít a sertéshúsból készült párizsi, ezt követi a baromfi- (kb. 49\%), a pulyka(40\%) és marhapárizsi (durván 36\%).

A párizsi-márkák is játszhatnak bizonyos szerepet a vásárlás során (ez volt a 4 . legfontosabb szempont párizsi vásárlás során), a vásárlók többsége $(60 \%)$ próbálja ugyanazon márkát beszerezni, emellett még a vevők ötöde mindig ugyanazt szerzik be. A legtöbbször említett márkanév a Pick és a Sága volt, itt is tapasztalható volt, hogy a párizsi-fogyasztók bizonyos része nem feltétlen vannak tisztában a termékkel kapcsolatban. Ugyanis többen említették párizsi márkaként a Zala-felvágottat és a Sága Falni Jó! Csemege terméket (ez utóbbit nem nevezhetjük párizsinak a 41\%-os MSM-tartalma és a $0 \%$-os hústartalma miatt).

Az összes kitöltő kb. 54\%-a szokott párizsit vásárolni, a vásárlók közel 29\%-a havi egyszer, 23\%-uk kéthetente, $20 \%$-uk pedig hetente szerez be párizsit, amelynek során a vevők több, mint a fele egyszerre 15-30 dkg-ot vesz egy alkalommal, főként 
szeletelt formában (kb. 78\% az arány). Vagyis megállapítható ezek alapján, hogy inkább kevesebb mennyiséget szereznek be szeletelten, mint egyszerre pl. 1 kg-os rúd kiszerelést.

A párizsi-vásárlók jelentős része maximum 750 forint értékig vesznek parizert, emellett érezhető az is, hogy többségük még kevesebb összegért vásárolnak. A vásárlók föként hiper- vagy szupermarketben szerzik be a terméket, ez köszönhető a nagyobb választéknak és húspultnak.

A vásárlás legfontosabb szempontjai közé a párizsi belső tulajdonságai tartoznak, ezek közül is a legfontosabb a párizsi íze, amit a termékkel kapcsolatos első benyomás követ. Amely meglepő lehet, a parizer ára csak a 7. legfőbb szempontnak számít a beszerzés során, megelőzve többek között az adott párizsi kapcsán kapott más fogyasztók véleményét, reklámokat.

\section{Irodalomjegyzék}

1333/2008/EK rendelet az élelmiszer-adalékanyagokról.

A Magyar Élelmiszerkönyv 1-3/13-1 számú előírása a húskészítményekről és egyes előkészített húsokról (48/2016. (VII. 18) FM rendelet a Magyar Élelmiszerkönyv kötelező elöírásairól szóló 152/2009. (XI. 12.) FVM rendelet módosításáról).

Európai Bizottság: Kérdések és válaszok az élelmiszer-adalékokról. $<$ https:/ec.europa.eu/commission/presscorner/detail/hu/MEMO_11_783> (2021.03. 05.)

HVG: WHO: Rákkeltö a kolbász és a szalonna, és valószínüleg a vörös húsok is. <https://hvg.hu/plazs/20151026_WHO_Rakkelto_a_kolbaszt_es_a_szalonna_es> (2021. 03. 10.)

Kesjár Sz., Balsa-Budai N., Soós M. (2017): Kolbászfogyasztási szokások vizsgálata Magyarországon. Élelmiszer, Táplálkozás és Marketing, 13 (2): 25-32.

Központi Statisztikai Hivatal (2021c): Az egy före jutó éves élelmiszer-fogyasztás mennyisége régió és települések típusa szerint $<$ http://www.ksh.hu/stadat files/jov/hu/jov0051.html > (2021. 03. 13.)

Központi Statisztikai Hivatal (2021b): Egyes termékek és szolgáltatások éves fogyasztói átlagára (1996-) (2/2). <https://www.ksh.hu/docs/hun/xstadat/xstadat_eves/i_qsf003b.html> (2021. 03. 11.)

Központi Statisztikai Hivatal (2021a) Egyes termékek és szolgáltatások havi, országos fogyasztói átlagára (1/9). <https://www.ksh.hu/docs/hun/xstadat/xstadat_evkozi/e_qsf005a.html> (2021. 03. 11.)

Mihalkó, J.: Párizsi-fogyasztási és -vásárlási szokások vizsgálata (kérdőív). $<$ https://docs.google.com/forms/d/e/1FAIpQLScTT_rF2f8gS4abF6mHbhafsJNe4ES_DywPb5

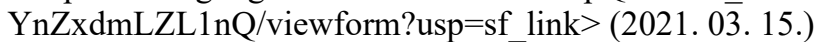

Mihalkó, J., Zsarnóczay, G. (2019.). Különböző alapanyagokból származó "párizsik" összehasonlító elemzése. Konzervújság, 67 (1-4.): 25-33.

Nébih: Európa élelmiszer-adalékanyagainak újraértékelése. <https://portal.nebih.gov.hu/-/europaelelmiszer-adalekanyagainak-ujraertekelese $>$ (2021.03. 14.)

Szabó, P. B. (2018): Élelmiszerek és egészséges táplálkozás. Szegedi Tudományegyetem, Szeged. $<$ http://eta.bibl.u-szeged.hu/716/>

Szakály Z. (szerk.) (2017): Élelmiszer-marketing. Akadémiai Kiadó, Budapest. $<$ https://mersz.hu/kiadvany/262/dokumentum/info/> 